\title{
Weighing the risks and benefits of intervention
}

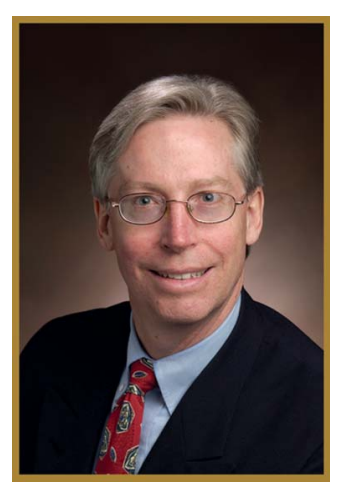

$\mathrm{K}$

nowledge, clinical judgment, and the relationship between practitioner and patient all inform decision-making surrounding diagnostic and therapeutic is especially challenging. In this issue of Neurology ${ }^{\circledR}$ Clinical Practice, Bartleson and Maus present a 3-part Drugs and Devices series examining diagnostic and therapeutic spinal interventions: facet joint interventions (p. 342); epidural injections (p. 347); and diskography (p. 353). In an accompanying editorial, Franklin and Markman (p. 277) emphasize: "It is critical that neurologists understand the complex tradeoffs of risk and benefit that invariably go along with addressing the pain symptoms that are often at the heart of disability claims."

The number of civilians and military personnel confronting disability due to traumatic peripheral nerve injury has grown over the past 2 decades. A Clinical and Ethical Challenges article by Smith et al. (p. 280) discusses ethical considerations and the complexities of shared decision-making in elective amputation following peripheral nerve injury. The authors emphasize the importance of "respect for autonomy, beneficence, nonmalfeasance, and justice...while trying to determine what the physician's role should be for these patients..."

Two articles in the Eye on Practice section tackle the intricacies of the intersection of the medical and legal professions. Woodcock (p. 329) offers advice on incorporating medical legal consultation into a neurology practice. Cheshire and Hutchins (p. 335) discuss professionalism and additional ethical implications of serving as an expert witness in a courtroom.

The debate regarding the nature of physician-Pharma interactions continues in our correspondence section, The Nerve! Please add your thoughts to the discussion!
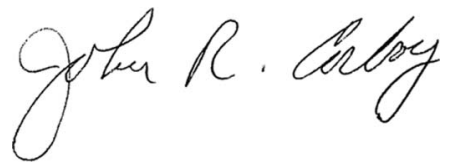

John R. Corboy, MD, FAAN 


\title{
Neurology ${ }^{\circ}$ Clinical Practice
}

\author{
Weighing the risks and benefits of intervention \\ Neurol Clin Pract 2014;4;271 \\ DOI 10.1212/CPJ.0000000000000051
}

This information is current as of August 18, 2014

\section{Updated Information \& Services}

Permissions \& Licensing

Reprints including high resolution figures, can be found at:

http://cp.neurology.org/content/4/4/271.full.html

Information about reproducing this article in parts (figures,tables) or in its entirety can be found online at:

http://cp.neurology.org/misc/about.xhtml\#permissions

Information about ordering reprints can be found online: http://cp.neurology.org/misc/addir.xhtml\#reprintsus

Neurol Clin Pract is an official journal of the American Academy of Neurology. Published continuously since 2011, it is now a bimonthly with 6 issues per year. Copyright ( 2014 American Academy of Neurology. All rights reserved. Print ISSN: 2163-0402. Online ISSN: 2163-0933.

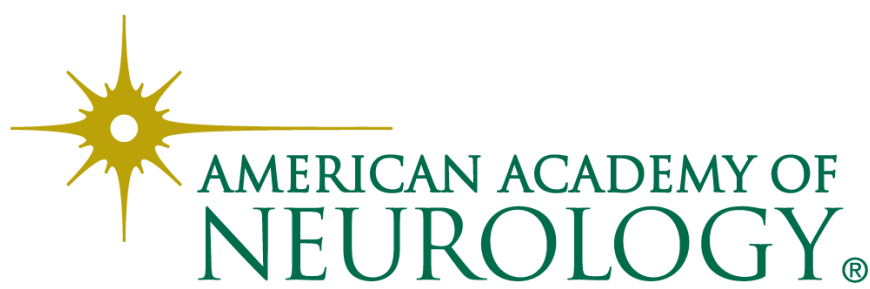

